\title{
The Effect of Curcumin (as Meriva) on Absolute Lymphocyte Count (ALC), NK Cells and T Cell Populations in Patients with Stage 0/1 Chronic Lymphocytic Leukemia
}

\author{
Terry Golombick ${ }^{*}$, Terrence H. Diamond ${ }^{1}$, Arumugam Manoharan ${ }^{2}$, Rajeev Ramakrishna ${ }^{2}$ \\ ${ }^{1}$ Department of Endocrinology, St George Hospital, Sydney, Australia \\ ${ }^{2}$ Southern Sydney Haematology, University of Wollongong, Wollongong, Australia \\ Email: "terry.golombick@sesiahs.health.nsw.gov.au, terrydiamond@optusnet.com.au, \\ a.manoharan@bigpond.com, medraj58@hotmail.com
}

Received 10 June 2015; accepted 10 July 2015; published 13 July 2015

Copyright $@ 2015$ by authors and Scientific Research Publishing Inc.

This work is licensed under the Creative Commons Attribution International License (CC BY).

http://creativecommons.org/licenses/by/4.0/

(c) (i) Open Access

\section{Abstract}

Purpose: To determine the effect of curcumin (as Meriva) on absolute lymphocyte count (ALC), T cell populations and NK cells in patients with Rai stage $0 / 1$ chronic lymphocytic leukemia (CLL) over a period of six months. Experimental Design: Twenty-one patients with significant lymphocytosis ( $>20 \times 10^{9}$ lymphocytes/L) and stage $0 / 1$ CLL were recruited into the study and received oral curcumin 2 grams/day. Blood samples were collected at baseline and at 2 monthly intervals for six months for full blood count, leukocyte surface antigens, liver function, serum biochemistry, immunoglobulins, CRP and ESR. A positive biologic response was defined as a reduction in the ALC of more than $20 \%$ from pre-treatment levels. Results: Four patients $(20 \%)$ demonstrated more than $20 \%$ decrease in ALC, three of whom had lower ALC at the end of the study as compared to baseline. The decrease in ALC was accompanied by an increase in CD4, CD8 and NK cells. No demonstrable response was seen in seventeen patients $(80 \%)$ who exhibited stable, fluctuating or increasing ALC during the study. Conclusion: A subgroup of stage 0/1 CLL patients may be responsive to curcumin therapy. The beneficial response appears to be immunomodulated.

\section{Keywords}

Stage 0/1 Chronic Lymphocytic Leukemia, Curcumin

"Corresponding author.

How to cite this paper: Golombick, T., Diamond, T.H., Manoharan, A. and Ramakrishna, R. (2015) The Effect of Curcumin (as Meriva) on Absolute Lymphocyte Count (ALC), NK Cells and T Cell Populations in Patients with Stage 0/1 Chronic Lymphocytic Leukemia. Journal of Cancer Therapy, 6, 566-571. http://dx.doi.org/10.4236/jct.2015.67061 


\section{Introduction}

Chronic lymphocytic leukemia (CLL) is the most common type of leukemia in the Western world [1]. It involves mature-appearing defective neoplastic lymphocytes (almost always B cells) with an abnormally long life span. The peripheral blood, bone marrow, spleen, and lymph nodes undergo leukemic infiltration. Nonspecific symptoms include fatigue and malaise and are usually attributable to the anemia. Clinical signs include lymphadenopathy, splenomegaly and hepatomegaly. Diagnosis is confirmed by examination of peripheral smear and bone marrow aspirate. Patients with CLL have been shown to have elevated T cell (CD3, CD4 and CD8) and NK cell populations [2]. A higher number of $\mathrm{T}$ and NK cells have been associated with delayed disease progression and time to treatment [3].

Unlike most malignant disorders in which early diagnosis increases the probability of a patient cure, treatment of unselected early-stage CLL patients with chemotherapy is associated with increased toxicity and no increase in survival [4] [5]. There is no published intervention that alters the course of disease for patients with early stage CLL i.e. Stage 0 or 1 disease (Rai staging system) [6]. These patients are usually monitored and commence therapeutic intervention if there is disease progression. This approach may often lead to patient's anxiety. These patients represent an excellent cohort to evaluate the efficacy of nutraceutical agents (with a favourable toxicity) for disease prevention or delay in disease progression (PD).

Nutraceutical agents such as epigallocatechin gallate (EGCG) derived from green tea, and curcumin, derived from turmeric, have been proposed as health-promoting substances that may reduce cancer risk. Phase 1 and 2 studies using oral green tea extract (EGCG) [7]-[9] have shown that patients with low grade CLL with/out lymphadenopathy demonstrate durable declines in ALC, suggesting an anti-cancer responsiveness.

Curcumin has been shown to be a potent cytotoxic agent for primary CLL B cells by inhibiting specific prosurvival pathways such as STAT3, AKT and NF-kB [10]. Moreover, curcumin also suppresses the expression of the anti-apoptotic proteins Mcl-1 and X-linked inhibitor of apoptosis protein (XIAP), and up-regulates the pro-apoptotic protein BIM. A combination of green tea extract and curcumin selectively upregulates STAT3 protein and its phosphorylation status when administered in co-culture of CLL B cells with stromal cells, while curcumin alone is able to overcome the stromal-induced protection when administered with EGCG in a sequential fashion [11]. These data suggest a potential therapeutic role for curcumin in the treatment of stage 0/1 CLL.

We administered curcumin as Meriva, a standardized mixture of natural curcuminoids and lecithin in a 1:2 ratio [12] [13], to 21 individuals with stage 0/1 CLL to determine 1) its effect on ALC, and 2) whether any observed effect could be mediated by the numbers of CD4, CD8 and NK cells. Our previous data has demonstrated the safety and efficacy of this compound in MGUS/SMM patients [14]-[17]. Meriva was chosen for this study based on its increased absorption and bioavailability.

\section{Materials and Methods}

Twenty-one patients with significant lymphocytosis $\left(>20 \times 10^{9}\right.$ lymphocytes/L) and Rai stage 0 (early CLL and lymphocytosis) or stage 1 (CLL and lymphadenopathy) were recruited. Blood was collected at 6 and 3 months prior to commencement of therapy, at 2 monthly intervals for a period of six months during therapy and at 3 months after completion of therapy. Patients were administered oral curcumin (as Meriva) 2 grams/daily in a divided dose. Blood samples were collected for full blood count, leukocyte surface antigens, liver function, serum biochemistry, immunoglobulins, CRP and ESR at each visit. A positive biologic response was defined as more than 20\% reduction in the ALC from the pre-treatment (baseline) levels.

The protocol was reviewed and approved by the South Eastern Sydney and Illawarra ethics committee. All patients provided written informed consent before study enrolment in accordance with the Declaration of Helsinki.

\section{Results}

There were 14 men and 7 women with mean age of $68( \pm 12.8)$ years and mean baseline ALC of $30.1 \times 10^{9}$ cells/L (normal $1.0-4.0 \times 10^{9} / \mathrm{L}$ ). Table 1 and Table 2 show the mean baseline clinical and immunological data. Twenty-one patients completed 2 months of the study, 3 withdrew at month 2 and a further 2 at month 4 . Most patients in this study had elevated baseline populations of CD4 (mean $2.2 \times 10^{9} / \mathrm{L}$, normal $0.7-2.1 \times 10^{9} / \mathrm{L}$ ), CD8 (mean $2 \times 10^{9} / \mathrm{L}$, normal $0.2-0.9 \times 10^{9} / \mathrm{L}$ ) and NK (mean $1.1 \times 10^{9} / \mathrm{L}$, normal $0.05-0.6 \times 10^{9} / \mathrm{L}$ ) cells and 
low IgM values (mean $0.3 \mathrm{~g} / \mathrm{L}$, normal 0.48 - $3.04 \mathrm{~g} / \mathrm{L}$ ).

There were four patients (20\%) who demonstrated a positive biologic response i.e. $>20 \%$ reduction in ALC during the course of the study (Table 3). Their pre-study, during study and post-study ALC values are shown in Table 3. Three of the four had a lower ALC at the end of the 6 month study period. All four patients showed a relapse and an increase in ALC at three months post-study drug withdrawal. The decrease in ALC was accompanied by an increase in the CD4 count in all 4 patients (100\%) after 2 months of curcumin therapy, and an increase in CD8 and NK cells in 2 (50\%) patients after 2 months of curcumin therapy. The elevated CD4, CD8 and NK cell counts returned to baseline values at 6 months in all patients. The mean CD4, CD8 and NK cell populations at baseline and during the study are shown in Table 4.

Seventeen patients (80\%) failed to show a positive response to curcumin therapy. They showed stable, fluctuating or increases in ALC during the course of the study (Table 5). The pre-study, during study and post-study ALC values of these patients are shown in Table 5. Among the non-responders, 6 (35\%) showed an increase in CD4 count after 2 months of curcumin therapy, 4 (23\%) showed an increase in CD8 count and 4 (23\%) showed an increase in NK cell count after 2 months of curcumin therapy.

Table 1. Mean baseline clinical and haematological data in all patients.

\begin{tabular}{|c|c|c|c|c|c|c|c|c|}
\hline & Age & $\begin{array}{c}\text { WCC } \\
\left(4-11 \times 10^{9} / \mathrm{L}\right)\end{array}$ & $\begin{array}{c}\text { ALC } \\
\left(1-4 \times 10^{9} / \mathrm{L}\right)\end{array}$ & $\begin{array}{c}\mathrm{Hb} \\
(130-180 \mathrm{~g} / \mathrm{L})\end{array}$ & $\begin{array}{c}\text { Pltlts } \\
(150-450 \times \\
\left.10^{9} / \mathrm{L}\right)\end{array}$ & $\begin{array}{c}\mathrm{LDH} \\
(120-250 \mathrm{U} / \mathrm{L})\end{array}$ & $\begin{array}{c}\text { ALT } \\
(5-40 \mathrm{U} / \mathrm{L})\end{array}$ & $\begin{array}{c}\text { Hct } \\
(0.39-0.54)\end{array}$ \\
\hline Mean \pm SD & $68 \pm 12.8$ & $35.0 \pm 9.9$ & $30.1 \pm 10.1$ & $142.3 \pm 12.7$ & $185.9 \pm 49.7$ & $196.7 \pm 34.2$ & $27.1 \pm 14.9$ & $0.43 \pm 0.03$ \\
\hline
\end{tabular}

Table 2. Mean baseline immunological data in all patients.

\begin{tabular}{|c|c|c|c|c|c|c|c|c|c|c|c|c|c|c|}
\hline & $\begin{array}{c}\text { IgG } \\
(6.2- \\
14.4 \mathrm{~g} / \mathrm{L})\end{array}$ & $\begin{array}{c}\operatorname{IgA} \\
(0.6- \\
3.96 \mathrm{~g} / \mathrm{L})\end{array}$ & $\begin{array}{c}\text { IgM } \\
(0.48-3 \\
\text { g/L) }\end{array}$ & $\begin{array}{c}\text { CD3 } \\
(0.7-2.1 \\
\left.\times 10^{9} / \mathrm{L}\right)\end{array}$ & \%CD3 & $\begin{array}{c}\text { CD4 } \\
(0.4-1.4 \\
\left.\times 10^{9} / \mathrm{L}\right)\end{array}$ & \%CD4 & $\begin{array}{c}\text { CD8 } \\
(0.2-0.9 \\
\left.\times 10^{9} / \mathrm{L}\right)\end{array}$ & \%CD8 & $\begin{array}{c}\text { CD 4/8 } \\
(1-3)\end{array}$ & $\begin{array}{c}\text { NK } \\
(0.05-0.6 \\
\left.\times 10^{9} / \mathrm{L}\right)\end{array}$ & \% NK & $\begin{array}{c}\text { CD19 } \\
(0.05-0.5 \\
\left.\times 10^{9} / \mathrm{L}\right)\end{array}$ & \%CD19 \\
\hline $\begin{array}{c}\text { Mean } \pm \\
\text { SD }\end{array}$ & $\begin{array}{c}8.8 \pm \\
2.8\end{array}$ & $\begin{array}{c}1.3 \pm \\
0.9\end{array}$ & $\begin{array}{c}0.3 \pm \\
0.2\end{array}$ & $\begin{array}{c}4.7 \pm \\
2.3\end{array}$ & $\begin{array}{c}17 \pm \\
9.3\end{array}$ & $\begin{array}{c}2.3 \pm \\
1.2\end{array}$ & $\begin{array}{c}8.2 \pm \\
4.5\end{array}$ & $\begin{array}{l}2 \pm \\
1.4\end{array}$ & $\begin{array}{l}7 \pm \\
5.2\end{array}$ & $\begin{array}{c}1.5 \pm \\
0.7\end{array}$ & $\begin{array}{c}1.1 \pm \\
0.7\end{array}$ & $\begin{array}{c}3.9 \pm \\
2.6\end{array}$ & $\begin{array}{c}24.5 \pm \\
10.1\end{array}$ & $\begin{array}{c}79.7 \pm \\
9.9\end{array}$ \\
\hline
\end{tabular}

Table 3. ALC counts of responding patients at 6 months and 3 months pre-study, during study and 3 months post-study.

\begin{tabular}{|c|c|c|c|c|c|c|c|}
\hline Patient No. & $\begin{array}{c}-6 \\
(n=4)\end{array}$ & $\begin{array}{c}-3 \\
(n=4)\end{array}$ & $\begin{array}{c}0 \\
(n=4)\end{array}$ & $\begin{array}{c}2 \\
(n=4)\end{array}$ & $\begin{array}{c}4 \\
(n=3)\end{array}$ & $\begin{array}{c}6 \\
(n=3)\end{array}$ & $\begin{array}{c}+3 \\
(n=3)\end{array}$ \\
\hline 1 & 24.9 & 22.8 & 26 & 18.2 & & & 20.2 \\
\hline 4 & 32 & 34.4 & 43.9 & 42.3 & 34.3 & 41.3 & 44.3 \\
\hline 9 & 48.5 & 43.9 & 49.9 & 30.2 & 31.1 & 36.7 & 43.2 \\
\hline 11 & 18.3 & 29.5 & 38.3 & 38.7 & 24.7 & 40.6 & \\
\hline Mean \pm SD & $30.9 \pm 12.9$ & $32.7 \pm 8.9$ & $39.5 \pm 10.2$ & $32.3 \pm 10.7$ & $30 \pm 4.9$ & $39.5 \pm 2.5$ & $35.9 \pm 13.6$ \\
\hline
\end{tabular}

Table 4. CD4, CD8 and NK cell counts (Mean \pm SD) in responding and non-responding patients.

\begin{tabular}{|c|c|c|c|c|c|c|c|}
\hline & Baseline & 2 months & p-value & 4 months & p-value & 6 months & p-value \\
\hline CD4 resp. & $1.38 \pm 0.5(n=4)$ & $2.93 \pm 1.6(n=4)$ & 0.1 & $1.11 \pm 0.4(n=3)$ & 0.1 & $1.2 \pm 0.3(\mathrm{n}=3)$ & 0.1 \\
\hline CD8 resp. & $2 \pm 1.5(n=4)$ & $2.68 \pm 1.9(n=4)$ & 0.3 & $1.8 \pm 1.2(\mathrm{n}=3)$ & 0.3 & $1.4 \pm 0.3(n=3)$ & 0.3 \\
\hline CD8 non-resp. & $2.03 \pm 1.4(n=17)$ & $1.61 \pm 0.9(n=17)$ & 0.1 & $1.63 \pm 0.9(n=15)$ & 0.9 & $1.5 \pm 0.7(n=13)$ & 0.3 \\
\hline NK resp. & $1.11 \pm 0.3(n=4)$ & $1.46 \pm 0.7(n=4)$ & 0.3 & $0.69 \pm 0.5(n=3)$ & 0.3 & $0.83 \pm 0.3(n=3)$ & 0.3 \\
\hline NK non-resp. & $1.06 \pm 0.8(n=17)$ & $1.09 \pm 0.7(n=17)$ & 0.9 & $1 \pm 0.6(n=15)$ & 0.3 & $1.2 \pm 0.9(\mathrm{n}=13)$ & 0.3 \\
\hline
\end{tabular}


Table 5. ALC counts of non-responding patients at 6 months and 3 months pre-study, during study and 3 months poststudy.

\begin{tabular}{|c|c|c|c|c|c|c|c|}
\hline Patient No. & $\begin{array}{c}-6 \\
(\mathrm{n}=17)\end{array}$ & $\begin{array}{c}-3 \\
(\mathrm{n}=17)\end{array}$ & $\begin{array}{c}0 \\
(n=17)\end{array}$ & $\begin{array}{c}2 \\
(n=17)\end{array}$ & $\begin{array}{c}4 \\
(n=15)\end{array}$ & $\begin{array}{c}6 \\
(n=13)\end{array}$ & $\begin{array}{c}+3 \\
(\mathrm{n}=15)\end{array}$ \\
\hline 2 & 34.3 & 31.1 & 30.7 & 40.2 & 30.6 & 51.5 & 30 \\
\hline 3 & 50.9 & 47.4 & 44.1 & 45.8 & 49.3 & 55.7 & 63.6 \\
\hline 5 & 23.3 & 25.4 & 25.9 & 25.3 & 23.4 & 27.0 & 32.3 \\
\hline 6 & 32.9 & 37.2 & 23.9 & 24.1 & 28.4 & 23.3 & 33.4 \\
\hline 7 & 13.8 & 18.3 & 14.6 & 17.9 & & & 12.8 \\
\hline 8 & 30.2 & 37.9 & 33.9 & 30.4 & 36.2 & & 36.5 \\
\hline 10 & 17.8 & 17.2 & 21.7 & 18.6 & 19 & & \\
\hline 12 & 43.9 & 43.9 & 38.3 & 40 & & & \\
\hline 13 & 20.7 & 23.2 & 20.2 & 23.2 & 19.8 & 27.4 & 25.8 \\
\hline 14 & 21.5 & 25.7 & 18.9 & 29.9 & 26.7 & 24.5 & 27.9 \\
\hline 15 & 21.8 & 17.4 & 23.8 & 23.7 & 28.2 & 29.7 & 37.9 \\
\hline 16 & 16.1 & 22.9 & 25.3 & 30.6 & 35 & 38 & 36.5 \\
\hline 17 & 20.4 & 25.7 & 29.3 & 25.9 & 24.2 & 39.3 & 47.7 \\
\hline 18 & 41.2 & 32 & 44.8 & 45.2 & 56.5 & 54 & 54.7 \\
\hline 19 & 41.2 & 45.5 & 35.8 & 40.3 & 35.9 & 35.8 & 51.8 \\
\hline 20 & 17.6 & 20.8 & 18.9 & 21 & 19.5 & 19.3 & 20.2 \\
\hline 21 & 20.9 & 18.7 & 23.1 & 19.9 & 23.7 & 23.9 & 24.9 \\
\hline Mean \pm SD & $27.6 \pm 11.2$ & $28.8 \pm 10.2$ & $27.8 \pm 8.9$ & $29.5 \pm 9.4$ & $30.4 \pm 10.8$ & $34.6 \pm 12.4$ & $35.7 \pm 13.7$ \\
\hline
\end{tabular}

Responding patients (i.e. $>20 \%$ decrease in ALC) show a greater increase in T cell and NK cell response (increase in CD4, CD8 and NK cells with $\mathrm{R}=0.81,0.8$ and 0.7 respectively) as compared to the non-responders ( $\mathrm{R}$ $=0.09,0.05$ and -0.2 respectively).

\section{Discussion}

Our study results suggest that curcumin may be beneficial in a small subset of early CLL patients due to its anti-tumour activity. The decrease in ALC count seen in 4 (20\%) of these patients corresponded with an increase in CD4 T cells, a similar finding to Varalakshami [18] in their mouse model. An increase in CD8 T cell and NK cells was also seen in 2 of the responders and 4 of the non-responders, perhaps due to curcumin therapy. Immunomulation of CD4 T cell, CD8 T cell and NK cell subsets has been found in numerous studies on curcumin therapy [18]-[21].

There is a marked clinical heterogeneity in patients with CLL that is associated with a heterogeneous array of genetic and molecular defects [3]. The complexity of this malignancy is further increased by the interaction of leukaemia cells with the microenvironment. Leukaemia cells closely interact with accessory and immune cells that regulate their trafficking, survival and proliferation. Patients with leukemia have been shown to have elevated $\mathrm{T}$ and NK cell populations and the relative numbers of $\mathrm{T}$ and NK cells at diagnosis has been associated with clinical outcome. A study by Huergo-Zapigo [3] has shown that CLL patients with a relative CD8 count > 0.03 showed significantly longer time to treatment than those with lower numbers of CD8 T cells, suggesting that CD8 may modify disease progression. This suggests that the non malignant immune system may play an important role in the pathogenesis and progression of this malignancy and that the expansion of T cells observed in patients with CLL may be due, in part, to the expansion of anti-tumor T cells [2]. A possible role for curcu- 
min therapy may be further expansion of these anti-tumor $\mathrm{T}$ cells. Our results suggests that a decrease in the absolute lymphocyte count of responding patients may be due to an augmentation of the T cell response.

The expected pattern for the majority of patients with early CLL is a rising ALC and progressive lymphadenopathy. Fluctuations in ALC can be expected in a subset of patients with CLL. Our data supports these findings as shown by the ALC fluctuations seen in the non-responding patients (80\%).

Limitations of this study include the small number of patients and the number of patients who dropped out of the study. Among the 5 patients that did not complete the 6 month study, 2 withdrew due to gastro-intestinal disturbance caused by the curcumin. No other toxicity was noted in the remaining patients.

Curcumin has a high hydrolytic instability at physiological $\mathrm{pH}$ and an inherently low intestinal absorption. It is therefore poorly bioavailable, with only conjugates being generally detectable in plasma even after dosages as high as $12 \mathrm{~g} /$ day. Curcumin is sparingly soluble in both water and lipophilic organic solvents, but has polar groups that make it a good candidate for phospholipid complexation. A novel curcumin formulation was developed under the brand name Meriva by combining a standardized mixture of natural curcuminoids and lecithin in 1:2 ratio, with 2 parts of microcrystalline cellulose being added to improve the physical state. The relative absorption of a standardized curcuminoid mixture and its corresponding lecithin formulation (Meriva) was investigated in a randomized, double-blind, cross-over human study and total curcuminoid absorption was about 29-fold higher for Meriva than for its corresponding unformulated curcuminoid-like mixture [12] [13]. Thus Meriva was chosen for this study solving the issue of megadoses even though curcumin had been found to be safe even at doses as high as $12 \mathrm{~g}$ /day. There is safety data with a number of patients treated with curcumin for as long as 10 years at a dose of $6 \mathrm{~g} /$ day (Golombick et al. Unpublished Data).

Although current prognostic indicators [ZAP-70, CD38, IGHV mutation status, fluorescence in situ hybridization (FISH)] are able to identify early stage CLL patients at high risk of rapid disease progression, these tests are not routinely performed in our laboratory and were not performed as part of their work-up.

\section{Conclusion}

In conclusion, the results of this 6-month study suggest that a small percentage of early CLL patients may derive benefit from curcumin therapy by decreasing their ALC, perhaps through stimulating an immune response by increasing CD4, CD8 and NK cells. CD8 cytotoxic T lymphocytes are involved in antigen-specific tumor destruction and CD4 $\mathrm{T}$ cells are essential for helping the CD8 T cell-dependent tumor eradication. A number of nutraceutical agents have been shown to have an immunostimulatory effect and combining their action with curcumin may be synergistic. The analysis of the number of different subsets of $\mathrm{T}$ cells should be taken with caution since the functionality of these subsets may be diverse. Follow-up activation studies are suggested. Our results suggest that a larger study is warranted.

\section{References}

[1] Shanafelt, T., Byrd, J., Call, T., et al. (2006) Intitial Management of Newly Diagnosed, Early Stage, Chronic Lymphocytic Leukemia. An Update for the Internist. Annals of Internal Medicine, 145, 435-447. http://dx.doi.org/10.7326/0003-4819-145-6-200609190-00007

[2] Gonzalez-Rodriguez, A.P., Contesti, J., Huergo-Zapico, L., et al. (2010) Prognostic Significance of CD8 and CD4 T Cells in Chronic Lymphocytic Leukemia. Leukemia and Lymphoma, 51, 1829-1836. http://dx.doi.org/10.3109/10428194.2010.503820

[3] Huergo-Zapico, L., Acebes-Huerta, A., Gonzalez-Rodriguez, A.P., et al. (2014) Expansion of NK Cells and Reduction of NKG2D Expression in Chronic Lymphocytic Leukemia. Correlation with Progressive Disease. PLOS ONE, 9, 1-9. http://dx.doi.org/10.1371/journal.pone.0108326

[4] Dighiero, G., Maloum, K., Desablens, B., et al. (1998) Chlorambucil in Indolent Chronic Lymphocytic Leukemia: French Cooperative Group on Chronic Lymphocytic Leukemia. New England Journal of Medicine, 338, 1506-1514. http://dx.doi.org/10.1056/NEJM199805213382104

[5] Shustik, C., Mick, R., Silver, R., et al. (1988) Treatment of Early Chronic Lymphocytic Leukemia: Intermittent Chlorambucil versus Observation. Hematological Oncology, 6, 7-12. http://dx.doi.org/10.1002/hon.2900060103

[6] Cheson, B.D., Bennett, J.M., Grever, M., et al. (1996) National Cancer Institute-Sponsored Working Group Guidelines for Chronic Lymphocytic Leukemia: Revised Guidelines for the Diagnosis and Treatment. Blood, 87, 4990-4997.

[7] Shanafelt, T.D., Lee, Y.K., Call, T.G., et al. (2006) Clinical Effects of Oral Green Tea Extracts in Four Patients with Low Grade B-Cell Malignancies. Leukemia Research, 30, 707-712. http://dx.doi.org/10.1016/j.leukres.2005.10.020 
[8] Shanafelt, T.D., Call, T.G., Zent, C.S., et al. (2009) Phase I Trial of Daily Oral Polyphenon E in Patients with Asymptomatic Rai Stage 0 to II Chronic Lymphocytic Leukemia. Journal of Clinical Oncology, 27, 3808-3814. http://dx.doi.org/10.1200/JCO.2008.21.1284

[9] Shanafelt, T.D., Call, T.G., Zent, C.S., et al. (2013) Phase II Trial of Daily oral Polyphenon E in Patients with Asymptomatic Rai Stage 0 to II Chronic Lymphocytic Leukemia. Cancer, 119, 363-370. http://dx.doi.org/10.1002/cncr.27719

[10] Ghosh, A.K., Kay, N.E., Secreto, C.R. and Shanafelt, T.D. (2009) Curcumin Inhibits Prosurvival Pathways in Chronic Lymphocytic Leukemia B Cells and May Overcome Their Stromal Protection in Combination with EGCG. Clinical Cancer Research, 15, 1250-1258. http://dx.doi.org/10.1158/1078-0432.CCR-08-1511

[11] Angelo, L.S. and Kurzrock, R. (2009) Turmeric and Green Tea: A Recipe for B-Chronic Lymphocytic Leukemia. Clinical Cancer Research, 15, 1123-1125. http://dx.doi.org/10.1158/1078-0432.CCR-08-2791

[12] Mazzolani, F. (2012) Pilot Study of Oral Administration of a Curcumin-Phospholipid Formulation for Treatment of Central Serous Chorioretinopathy. Clinical Opthalmology, 6, 801-806.

[13] Cuomo, J., Appendino, G., Dern, A.S., et al. (2011) Comparative Absorption of a Standardized Curcuminoid Mixture and Its Lecithin Formulation. Journal of Natural Products, 74, 664-669. http://dx.doi.org/10.1021/np1007262

[14] Golombick, T. and Diamond, T. (2008) The Potential Role of Curcumin (Diferuloylmethane) in Plasma Cell Dyscrasias/Paraproteinemia. Biologics: Targets and Therapy, 2, 161-163. http://dx.doi.org/10.2147/BTT.S2514

[15] Golombick, T., Diamond, T., Badmaev, V., et al. (2009) The Potential Role of Curcumin in Patients with Monoclonal Gammopathy of Undefined Significance-Its Effect on Paraproteinemia and the Urinary N-Telopeptide of Type 1 Collagen Bone Turnover Marker. Clinical Cancer Research, 15, 5917-5922. http://dx.doi.org/10.1158/1078-0432.CCR-08-2217

[16] Golombick, T., Diamond, T., Manoharan, A. and Ramakrishna, R. (2012) Monoclonal Gammopathy of Undetermined Significance (MGUS), Smoldering Multiple Myeloma (SMM) and Curcumin: A Randomised, Double-Blind PlaceboControlled Cross-Over 4g Study and an Open-Label 8g Extension Study. American Journal of Hematology, 87, 455460. http://dx.doi.org/10.1002/ajh.23159

[17] Golombick, T., Diamond, T., Manoharan, A. and Ramakrishna, R. (2013) Long Term Use of Curcumin in Two Smoldering Multiple Myeloma Patients. Journal of Hematological Malignancies, 3, 18-23. http://dx.doi.org/10.5430/jhm.v3n1p18

[18] Varalakshmi, A.C., Mubarak, A., Pardhasaradhi, B.V.V., et al. (2008) Immunomodulatory Effects of Curcumin: InVivo. International Immunopharmacology, 8, 688-700. http://dx.doi.org/10.1016/j.intimp.2008.01.008

[19] Aggarwal, B.B., Kumar, A., Aggarwal, M.S. and Shisodia, S. (2005) Curcumin Derived from Turmeric (Curcuma longa): A Spice for All Seasons. In: Bagchi, D. and Preuss, H.G., Eds., Phytopharmaceuticals in Cancer Chemoprevention, CRC Press, Boca Raton, 349-387.

[20] Chang, Y.F., Chuang, H.Y., Hsu, C.H., et al. (2011) Immunomodulation of Curcumin on Adoptive Therapy with T Cell Functional Imaging in Mice. Cancer Prevention Research, 5, 444-452. http://dx.doi.org/10.1158/1940-6207.CAPR-11-0308

[21] Bhattacharyya, S., Hossain, D.M.S., Mohanty, S., et al. (2010) Curcumin Reverses T Cell-Mediated Adaptive Immune Dysfunctions in Tumor-Bearing Hosts. Cellular \& Molecular Immunology, 7, 306-315.

http://dx.doi.org/10.1038/cmi.2010.11 